\title{
METABOLISM OF THE DEVELOPING RETINA* III. RESPIRATION IN THE DEVELOPING NORMAL RAT RETINA AND THE EFFECT OF AN INHERITED DEGENERATION OF THE RETINAL NEURO-EPITHELIUM
}

\author{
BY \\ CLIVE GRAYMORE \\ Department of Pathology, Institute of Ophthalmology, University of London
}

Previous studies in this laboratory have established that the glycolytic activity of the rat retina is doubled between the 10th and 14th days of life. Elimination of the possibility that light stimulation per se is a causative factor, combined with histological considerations, led to the speculation that this sudden increase might be attributed to the differentiation of the visual cells (Graymore, 1958a; 1959).

Considerable support for this hypothesis was gained from the observation that subsequent loss of the visual cells, whether chemically induced or as a result of hereditary degeneration, resulted in a reversion of the glycolytic activity to that of the immature tissue (Graymore and Tansley, 1959a,b; Graymore, Tansley, and Kerly, 1959).

Comparative estimations of anaerobic and aerobic lactic acid accumulation prompted the suggestion that respiratory activity might well show a corresponding increase at this time of visual cell differentiation, and the purpose of the present communication is to describe experiments designed to test this hypothesis. Corresponding studies on the rat with retinitis pigmentosa are described, and the implications of these findings are discussed in relation to the role of the visual cell in retinal metabolism.

\section{Methods}

Animals.-The normal animals used in this investigation were albino rats of either sex, aged between 6 days and 3-4 months. Animals having the hereditary degeneration were albino and black-and-white rats of either sex, aged between 11 days and 3-4 months, all of which were bred from the original stock used by Bourne, Campbell, and Tansley (1938). All animals were fed ad lib. a diet used routinely in this laboratory (Bruce and Parkes, Diet 41, 1946).

Respiratory Activity.-The procedure for the isolation of the retinae was the same as that described previously (Graymore, 1958b). Oxygen uptake was determined manometrically by the indirect method of Warburg (1924), the incubating medium being Krebs-Ringer bicarbonate fortified with $200 \mathrm{mg}$. per cent. sodium pyruvate, and the gas phase being 5 per cent. $\mathrm{CO}_{2}-95$ per cent. $\mathrm{O}_{2}$. The buffer was gassed 
continuously whilst the retinae were being isolated and for a further $15 \mathrm{~min}$. after the flasks had been attached to the manometers. Initial readings were taken after a 10-min. equilibration period, and subsequent readings were taken over a period of one $\mathrm{hr}$, the flasks being shaken at a rate of $90 / \mathrm{min}$. and the temperature being maintained at $37^{\circ} \mathrm{C}$. Two flasks were employed for each single estimation, one of which contained twice as much buffer and tissue as the other. A total of six to eight retinae was required for each determination in the case of the mature animals and as many as twelve to sixteen in the case of the very young animals. The final result was expressed as the volume of oxygen in microlitres taken up by $1 \mathrm{mg}$. tissue protein in $1 \mathrm{hr}\left(\mathrm{qO}_{2}(\mathrm{pr})\right)$. Tissue protein was determined by the micro-Kjeldahl procedure.

Anaerobic Glycolytic Activity.-This was determined as described previously (Graymore, 1959), and is expressed as lactic acid production in terms of an equivalent volume of $\mathrm{CO}_{2}$ which would be liberated from the bicarbonate buffer by that quantity of acid. The final result is expressed as the volume of gas in microlitres liberated in $1 \mathrm{hr}$ by $1 \mathrm{mg}$. tissue protein. $\left(\mathrm{q}_{\mathrm{G}}^{\mathrm{N}_{2}}(\mathrm{pr})\right)$.

\section{Results}

Fig. 1 shows the respiratory activity of the rat retina from 5 days after birth until 3 to 4 months of age. It was explained in the methods section that a relatively large number of animals was required for each determination, so that, although a total of 82 animals was used, each point on the graph (with the exception of the last) represents a single result. The last point is the mean of eight results. Because of this the changes are not so precise as those seen in glycolysis, but nevertheless the general pattern is the same. The respiratory activity is almost doubled between 9 days (10.4) and 16 days (19.9), the final mature value being $26 \cdot 3 \pm 1 \cdot 5$.

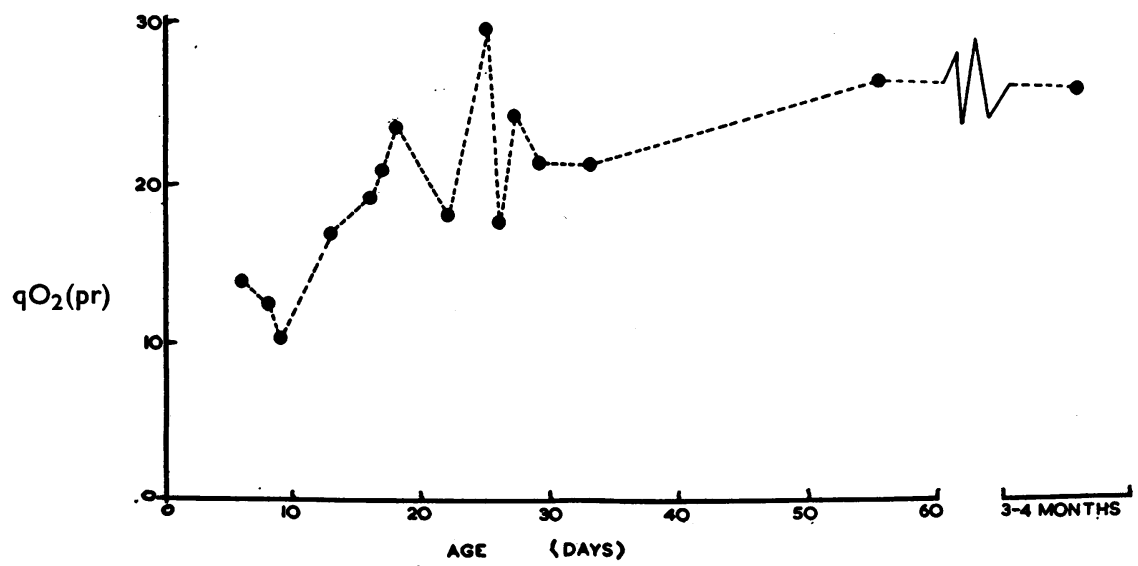

FIG. 1.-Respiratory activity of normal rat retina during development. 
The corresponding graph for retinae removed from rats with retinitis pigmentosa is shown in Fig. 2. Between ninety and one hundred rats were required for these determinations, and as before each point represents a single result with the exception of the last which is the mean of six results. Between 11 and 18 days the respiratory activity increases from $8 \cdot 8$ to $21 \cdot 2$. This level fluctuates but is maintained roughly until the 35th day, after which it falls precipitously to $12 \cdot 2$ by the 40 th day. The mature value is $9 \cdot 2 \pm 1 \cdot 6$.

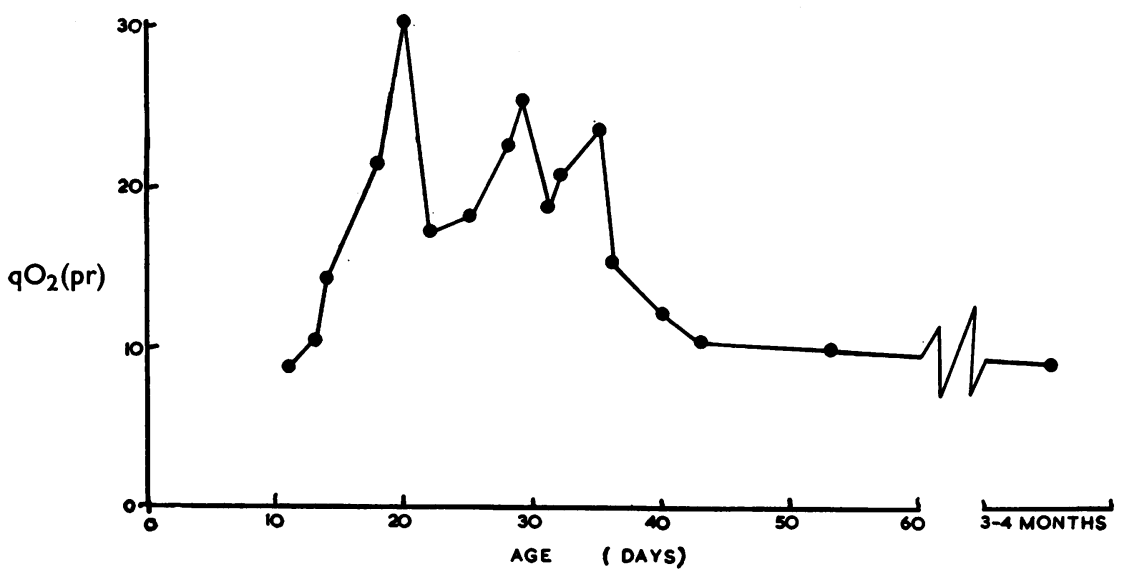

FIG. 2.-Respiratory activity of retinae from retinitis pigmentosa rats during development.

The Table shows the anaerobic glycolytic activity and the respiratory activity of normal and retinitis rats aged 31 to 32 days. For these determinations, single litters were divided into two groups and respiration and glycolysis studied on the same day under identical conditions. Only the difference in the glycolytic activity of the two groups is significant.

TABLE

RESPIRATORY ACTIVITY ( $\mathrm{qO}_{2}(\mathrm{pr})$ ) AND ANAEROBIC GLYCOLYTIC ACTIVITY $\left(q_{G}^{\mathbf{N}_{2}}(p r)\right)$ OF RETINAE FROM NORMAL AND RETINITIS PIGMENTOSA RATS AGED 31-32 DAYS

\begin{tabular}{|c|c|c|c|c|c|c|}
\hline \multicolumn{5}{|c|}{ Rats } & \multirow{2}{*}{$\frac{\mathrm{q}_{\mathrm{G}}^{\mathrm{N}_{2}(\mathrm{pr})}}{51 \cdot 2 \pm 2 \cdot 7(16)}$} & \multirow{2}{*}{$\begin{array}{c}\mathrm{qO}_{2}(\mathrm{pr}) \\
20 \cdot 8 \pm 1 \cdot 6(12)\end{array}$} \\
\hline Controls & . & .. & $\ldots$ & . & & \\
\hline Retinitis pigmentosa & ... & .. & $\ldots$ & .. & $\begin{aligned} 35 \cdot 9 & \pm 1 \cdot 5(29) \\
p & =<0.001\end{aligned}$ & $\begin{array}{c}17 \cdot 2 \pm 1 \cdot 7(14) \\
p=0.13\end{array}$ \\
\hline
\end{tabular}

$p=$ probability that difference from control value is due solely to chance. Number of determinations in parenthesis. 


\section{Discussion}

The respiratory activities recorded for the normal rat retina show a remarkable parallel with those observed previously for glycolysis both as regards the proportionate size of the increase as well as the age at which this increase occurs. The near doubling of activity between 9 days and 16 days observed in the present series is comparable with the rise in glycolytic activity between the 10th and 14th days of life reported previously (from $\mathrm{q}_{\mathrm{G}}^{\mathrm{N}_{2}}$ (pr)=26.1 to $\mathrm{q}_{\mathrm{G}}^{\mathrm{N}_{2}}$ (pr)=50.5, Graymore, 1959). In both cases this mature value is maintained.

As protein accounts for about 85 per cent. of the dry weight of the retinal tissue the present figures should be divided by 1.176 for purposes of comparison with figures quoted by other authors using the more conventional mg. dry weight basis. On this basis the mature value would become $22 \cdot 4$, being the mean of eight results ranging from $18 \cdot 0$ to $26 \cdot 3$. These activities have been recorded in bicarbonate buffer and confirm the high rate of retinal respiration observed when this buffer is used in preference to phosphate buffer (Laser, 1935). Values recorded by previous workers, using bicarbonate buffer, include 30.7 (Warburg, 1926), 20.3 (Dickens and Greville, 1933), $30 \cdot 7$ (Laser, 1935), 27.1 (Campos, 1936), and 34.0 (Craig and Beecher, 1943). The graph illustrating the respiratory activity of the rats with retinitis shows a close analogy to the pattern of glycolysis seen in these animals during development and reported in Paper II of this series (Graymore, Tansley, and Kerly, 1959). In this paper, the abiotrophic nature of the disease, as first described by Bourne, Campbell, and Tansley (1938), was confirmed. The retina appears to develop completely normally until 3 weeks of age, but immediately after maturing the visual components begin to degenerate. The present results show that the respiratory pattern is essentially normal until about the end of the 5th week of life, when the activity falls abruptly. By the end of the 6th week the $\mathrm{qO}_{2}(\mathrm{pr})$ has returned to $10 \cdot 5$, which is of the same order as that of the immature retina of less than 10 days of age.

Graymore and others (1959) stressed the difficulties involved in attempting to ascertain whether the observed decline in glycolytic activity preceded the pyknotic changes or whether it merely reflected the death of cells which in normal health exhibited a particularly high activity. The fall in glycolytic activity observed previously appeared to be much more abrupt than the accompanying degenerations, thus favouring the former possibility. On the other hand, conventional histological techniques demonstrate structural changes in the cell, but fail to reveal any information regarding the activity of the cell. It is not possible to distinguish between a dead cell which is gradually degenerating structurally, and a dying cell which is still maintaining some degree of activity. If some as yet unknown factor were responsible 
for cell death, glycolysis, serving as an index of activity, would fall abruptly, but the degeneration of the dead cells and the clearing away of the residual debris might take some weeks to complete. Such events might produce the histological and biochemical sequences observed. There are two contraindications to this explanation. Examination revealed that at 5 weeks, although the central part of the retina is becoming disorganized, the peripheral regions appear to be little affected. It would seem, therefore, that all the cells are not dying at the same rate, and if glycolysis merely reflects cell death, one would expect a more gradual loss of activity. Secondly, after chemical poisoning of the visual cells, the cell debris is removed completely within one week (Graymore and Tansley, 1959b).

It was hoped that the present investigation might help to clarify this problem. If cell deaths were a gradual process resulting from an abrupt failure of glycolysis, then the decline in activity of other processes characteristic of the living cell would lag behind that of glycolysis, whereas, if both glycolysis and this other property were results of cell death, then both might decline at the same rate, both being rates determined by a single independent factor.

In the experiments reported here, respiration declines between the 5th and 6th weeks, whereas it had been shown previously that glycolysis had returned to the immature value by the end of the 4th week. This rather slight time lag is not very convincing, however, when the extreme variability of the respiratory results is taken into account. The results of an attempt to assess the reality of this experimental difference are shown in the Table, which records the results of 72 determinations of respiration or glycolysis in retinae from animals aged 31-32 days. Both control and retinitis pigmentosa animals were used. It can be seen that lower values are recorded for both glycolysis and respiration in retinitis animals of this age, but the difference is smaller in the latter case and the variation greater. The difference between the means of the respiratory levels is not statistically significant $(p=0 \cdot 13)$, whereas the fall in glycolysis at this time is highly significant $(p=<0.001)$.

This lends some support to the possibility that the fall in glycolysis precedes that in respiration, and to the speculation that the fall in respiration could reflect cell death induced by glycolytic failure. There is not yet sufficient evidence, however, to state this with any certainty, for different enzymes or enzyme complexes might exhibit widely differing degrees of stability, and this could readily account for the slight difference in the observed time courses, without necessarily implying any interrelationship.

The rise and subsequent decline in respiratory activity between the second and fifth weeks of life, coinciding with the differentiation and degeneration of the visual components, suggest that the visual cells not only possess a very powerful glycolytic system but that they have a high oxidative potential. Evidence from other sources supports this concept. Francis (1953), detected high concentrations of succinic dehydrogenase in the inner segments of the 
visual cells, and Lowry, Roberts, and Lewis (1956), found these regions to be particularly rich in malic dehydrogenase. The electron microscope studies of Sjöstrand $(1949,1953)$ have clearly demonstrated dense aggregates of mitochondria in the ellipsoids.

Before this work was completed, Noell (1958) reported very briefly the results of studies carried out in conjunction with Cohen. These studies showed that, in the rabbit, respiration increases 3-fold between 12 and 20 days after birth and glycolysis shows a smaller increase rather earlier. By analogy with post-natal cerebral changes, he also arrived independently at the conclusion that this increased activity might be attributable to the differentiation of the visual cells. They investigated this problem further by destroying the visual cells of the mature rabbit with iodoacetate and measuring the activity of the surviving layers. They found that respiration was slightly lowered, aerobic glycolysis was reduced by 25 per cent., and anaerobic glycolysis was unaffected. On this basis it was concluded that, at the time of visual cell differentiation, all the layers of the retina undergo an increase of activity. It is difficult to reconcile these results with those reported here or with the work of Graymore and Tansley (1959b), in which it was shown that following the destruction of the visual cells chemically in the rat, the surviving layers of the retina showed only 50 per cent. of the glycolytic activity of the intact tissue. Noell's report, however, although taking the form of an excellent and comprehensive review, provides very little experimental information. Without this, it is not possible to attempt to explain these discrepancies. They employed a phosphate buffer for the iodoacetate experiments, and hence the glycolytic and respiratory values are rather low; the possibility that this difference in medium might account for the differing results cannot be overlooked, for there is an increasing weight of evidence suggesting that the metabolism of the retina may be fundamentally altered in the presence or absence of bicarbonate (Laser, 1935; Crane and Ball, 1951; Hopkinson and Kerly, 1959). A reduced potential for glucose utilization might not become apparent in circumstances where some ratelimiting factor is already imposed. Heald (1953), for example, found that iodoacetate inhibited the oxygen uptake of stimulated but not of resting brain tissue, and suggested that the lack of inhibition might be a reflection of submaximal activity. Hopkinson and Kerly (1959) confirmed the much higher rate of retinal oxidation in bicarbonate buffer than in phosphate buffer, and showed that a concentration of iodoacetate, which in vitro inhibited oxidation by 40 per cent. in bicarbonate buffer, had very little effect in phosphate buffer. On the other hand, although lower values are observed in phosphate buffer, Noell did observe an increase of activity during development using this buffer, and if this were due to the visual cells, removal of these cells should reverse the picture. In general, it may be concluded that the present studies on the behaviour of the rat retina in bicarbonate buffer suggest that the respiratory changes during development closely parallel those of glycolysis. 
At the time of visual cell differentiation there is an overall increase of activity, and the loss of this activity accompanying visual cell degeneration in retinitis pigmentosa rats provides support for the speculation that these bodies are particularly active metabolically. There is some evidence to suggest that in the case of the retinitis pigmentosa rats glycolytic potential is lost before that of respiration.

\section{Summary}

(1) The oxidation of pyruvate by retinal tissue incubated in bicarbonate buffer has been investigated during the development of the normal rat and the rat with hereditary visual cell degeneration.

(2) In both cases there is a doubling of respiratory capacity during the 2nd and 3rd weeks of life.

(3) The loss of the visual cells in the retinitis pigmentosa rats leads to a reversal of this development pattern.

(4) There is some evidence to suggest that the fall in respiratory activity accompanying these degenerations follows that reported previously for glycolysis.

(5) Some implications of these observations are discussed.

The continued interest and encouragement of Prof. Norman Ashton is gratefully acknowledged. I am pleased to be able to record my thanks to Mrs. Zelma Campbell for her excellent technical assistance and to Miss E. Fitzgerald for secretarial help. I am indebted to the Medical Research Council for a grant towards the expenses of this work.

\section{REFERENCES}

Bourne, M. C., CAMPBell, D. A., and TANSley, K. (1938). Brit.J. Ophthal., 22, 613.

Bruce, H. M., and Parkes, A. S. (1946). J. Hyg. (Lond.), 44, 501.

CAMPOS, R. (1936). Ann. Ottal., 64, 456.

Craig, F. N., and BeEcher, H. K. (1943). J. gen. Physiol., 26, 473.

Crane, R. K., and Ball, E. G. (1951). J. biol. Chem., 188, 819.

FrancIS, C. M. (1953). J. Physiol. (Lond.), 119, 38P.

GRAYMORE, C. N. (1958a). Biochem. J., 69, 30P.

(1958b). Brit. J. Ophthal., 42, 348.

(1959). Ibid., 43, 34.

and TANSLEY, K. (1959a). Ibid., 43, 177.

- (1959b). Ibid., 43, 486.

$\overline{\text { Heald, P. J. (1953). Ibid., 55, 625. }}$, Biochem. J., 72, 459.

HOPKINSON, L., and KERLY, M. (1959). Biochem. J., 72, 22.

LASER, H. (1935). Nature (Lond.), 136, 184.

LoWry, O. H., RoberTs, N. R., and LeWIS, C. (1956). J. biol. Chem., 220, 879.

NOELL, W. K. (1958). A.M.A. Arch. Ophthal., 60, 702.

SJöstrand, F. S. (1949). J. cell. comp. Physiol., 33, 383. (1953). Ibid., 42, 15.

WARBURG, O. (1924), Biochem. $Z$., 152, 51.

(1926). "Uber den Stoffwechsel der Tumoren". Springer, Berlin. 